\title{
Thinking Ahead: Strategic Foresight and Government Andrew Leigh"
}

\author{
Australian Journal of Public Administration \\ Vol 62 No 2, pp. 3-10 (lead article) \\ June 2003
}

\begin{abstract}
:
The technique of strategic foresight-developing policy based on long-run scenario planning - has much to offer Australian governments. By paying greater attention to identifying emerging issues, and drawing on a broad range of information sources, policies are more likely to prove durable and effective. Drawing on examples from the private sector, and from governments in the UK, US, and Australia, I outline what strategic planning entails, and how it might be implemented.

"In the early 1970s it [the US birthrate] hovered around 3 million births per year; forecasters at the US Census Bureau projected that this 'trend' would continue forever. Schools, which had been rushed into construction during the baby boom of the fifties and early sixties, were now closed down and sold. Policymakers did not consider that the birthrate might rise again suddenly. But a scenario might have considered the likelihood that the original baby boom children, reaching their late thirties, would suddenly have children of their own. In 1979, the US birthrate began to rise; it is now over the 4 million per annum of the fifties. Demographers also failed to anticipate that immigration would accelerate. To keep up with demand, the state of California (which had been closing schools in the late 1970s) must build a classroom every day for the next seven years."

Peter Schwartz, The Art of the Long View $(1991,6)$
\end{abstract}

How might governments anticipate and avoid the problems of the future? Can the opportunities that lie ahead be identified, and strategies created for making the most of them? Is there a way for governments to focus on the long run without locking themselves into rigid plans that limit their options when circumstances change?

This paper discusses how policymakers can improve the effectiveness of government by putting in place what Peter Schwartz calls "the art of the long view". The term I have used to describe this process is "strategic foresight" - reflecting the fact that governments should both anticipate future challenges, and identify possible strategies. Policymakers seeking to develop such a model should look to what has been done by governments around the world, as well as to the lessons from scenario planning in the private sector. Strategic foresight involves broadening the menu of policy options, and taking into account future scenarios that might affect today's decisions. In one sense, it is merely an extension of good policymaking. Yet many of the ideas of strategic foresight are quite different from the way in which most governments operate today.

\footnotetext{
* The author is a PhD student at the John F. Kennedy School of Government, Harvard University, and may be contacted at andrew_leigh@ksg02.harvard.edu. He thanks David Adams and Ben Hubbard for assistance in formulating the arguments in this paper, and Elaine Kamarck, Donald Speagle, and an anonymous referee for providing comments on an earlier draft. Naturally, these people should not be assumed to agree with its contents, and responsibility for all errors lies with the author.
} 
I outline below the major features of strategic foresight, before turning to five particular examples - President Nixon's short- lived National Goals Research Staff; the Victorian Government's successful Policy Development and Research Branch; the British government's foresight program; the private sector scenario planning work of Peter Schwartz (through Shell and the Global Business Network); and Lockheed Martin's Skunk Works.

These five examples represent a variety of perspectives on strategic foresight today. The two business case studies - Schwartz and Skunk Works - are widely recognised as leading innovators in their respective fields. The three public sector cases illustrate how strategic planning has worked in three different countries, and at different levels of politicisation. While the Nixon's NGRS was more partisan, the British foresight program appears to lie at the other end of the spectrum. The Victorian Policy Development and Research Branch is somewhere between the two. But as these three examples are intended to illustrate, the insights of strategic foresight are applicable in a variety of different contexts, from state government agencies to Federal Ministers' offices. Indeed, if the Senate is imbued with a greater role in strategic policymaking, as has been discussed on these pages (Marsh 2002; cf Norton 2002), the lessons of strategic foresight could usefully be employed.

Several features of bureaucracies have tended to mitigate against strategic foresight becoming an established feature of policymaking. Writing on the issue of reforming government, Sturgess (2001) lists eight characteristics of bureaucracies: systematisation, specialisation, tight coupling (between ministers and their departments), hierarchy, professionalism, impersonality, equity and accountability. Strategic foresight breaks with most of these characteristics. It is neither systematised nor specialised. It looks beyond ministerial needs, and often ignores hierarchies. And it is more difficult, though not impossible, to impose accountability on advice about future contingencies. It is little wonder, therefore, that strategic foresight has not evolved as an integral aspect of most Australian bureaucracies.

\section{Features of strategic foresight}

In Reinventing Government, Osborne and Gaebler (1992) noted that one of the important forms of innovation is "anticipatory government - prevention rather than cure". In certain areas, anticipatory government has a strong history. One such area is defence policy. For many centuries, defence and foreign policy makers have understood the importance of engaging in the chess-like exercise of thinking about how another country might respond to a given set of actions. In the decades following World War II, the RAND Corporation "pioneered the use of alternative futures (also called scenarios)" (Davis 1996, 48). These allowed policymakers to develop a fuller picture of the uncertainties in the system, and to use strategies to shape defence policy accordingly. In the circumstances of the Cold War, defence was an area of public policy "where Congress and the public were willing to grant the expert wide latitude and to relax somewhat the normal channels of political accountability" (Smith 1966, 317). RAND continues to be influential today, though the 
evolution of several other defence policy think-tanks has challenged its once-dominant position in debates on military issues.

Another area in which strategic forecasting has been utilized is macroeconomic policymaking. Particularly since the rise of Keynesianism ${ }^{1}$, economists have attempted to predict the economic cycle, with the hope of allowing governments to act quickly and limit the severity of the downswing. And lastly, recent decades have seen environmental forecasters playing a prominent role in the public debate over global warming.

Yet in most policy areas, government remains mired in day-to-day battles, and unable to focus on issues beyond the next election. Strategic foresight would involve not only better prediction, but also better use of those forecasts. For example, in the case of California's schools, both better demographic projections and a good understanding of the policy implications of those projections were critical. Gordon Robbins $(1995,6)$ has argued that this process is akin to developing two or three possible "plot lines", each suggesting one way in which a given issue might play out.

Having created such plot lines, Robbins emphasizes that it is important for policymakers to "avoid the temptation to become attached to a particular scenario outcome because it appeals emotionally, financially, or for some other reason" $(1995,8)$. Robbins points out that looking to the future should not cause policymakers to bind themselves into rigid positions. In this sense, strategic foresight is fundamentally different from the notion of five or ten year plans. At its best, the process allows policymakers to explore possible "futures", and pursue policies that are most likely to bring them to fruition.

In essence, there are five ways in which strategic foresight teams can contribute to more innovative government. ${ }^{2}$

1. Anticipating emerging issues. Foresight teams should consider how best to tackle potential problems, from looming environmental hazards to the risk of an economic slowdown. They should also aim to spot opportunities for policy development. The appropriate horizon over which they ought to operate will vary from issue to issue - in the case of environmental dangers, one or two generations may be appropriate, while for economic scenarios, 1-5 years may be all that can be anticipated with any reasonable degree of certainty. In the business context, Michael Porter has argued: "strategic positions should have a horizon of a decade or more, not of a single planning cycle" $(1996,74)$. In politics, foresight teams should certainly not be afraid to project beyond the next election.

2. Identifying unanticipated consequences. Foresight can help to shift the focus of bureaucrats and politicians onto emerging risks and opportunities, and highlight the unintended consequences of their proposals. This becomes particularly important as the risks that confront our society become increasingly complex. As Ulrich Beck (1992) has pointed out, many risks are now ubiquitous, global and increasingly invisible, potentially

\footnotetext{
${ }^{1}$ On the continuing influence of Keynesian economics in policymaking, see Krugman (1994, 197-220).

${ }^{2}$ This list is a combination of factors listed in Grant (1988) and Schwartz (1991).
} 
transcending the ability of our current struc tures to deal with them. The challenge to policymakers is to engage in the "active exploration of risk environments" (Giddens 1998,63 ) in order to be able to effectively manage these new hazards.

3. Getting a sense of the "big picture". A critical feature of foresight is that it is not bounded by traditional demarcations between agencies or issues. Foresight should help to foster "holistic governance" by looking at issues that crosscut departmental boundaries such as social capital, innovation and globalisation. It should take into account the government's fiscal priorities, environmental and economic forecasts, social trends, and the political feasibility of achieving a particular outcome. Foresight teams should have the capacity to undertake high- level statistical analysis, and to commission research and polling where necessary. Strategic foresight advice should be broadly based, and wherever possible backed up by empirical evidence, so that it can be contested and debated by others in the policy domain.

4. Drawing on a wide range of information sources. To effectively spot new trends, strategic foresight teams need to have a much wider range of information sources than most governmental bodies. They should be constantly drawing upon academics, think tanks, and the work of governments around the world. Below, I outline the radical methods used by Schwartz, who argues that to spot trends, it is necessary to take account of a wide variety of sources, including popular perceptions, new scientific breakthroughs, fringe conventions and even music trends (1991, 62-73). While this will not always be appropriate for governments, strategic foresight teams can nonetheless learn from his strategy of casting a wide net when trawling for new information.

5. Involving the public. Strategic foresight need not simply be aimed at affecting the views of senior policymakers. One model, best epitomized by the British foresight program (see below), is to consult widely and then to produce public reports. These will often take the form of what Lindsey Grant $(1988,11)$ calls "The World in XXXX" reports. Within the US, perhaps the most significant such report was The Global 2000 Report to the President. Commissioned by President Carter in 1977, it forecast the probable changes in the earth's climate until the end of the twentieth century. Global 2000 had a substantial effect on public thinking about global warming, and was heavily debated in both scholarly and popular journals. On a smaller scale, the Brookings Institution recently released a report on government's greatest challenges over the next half century (Light 2001), with the implicit aim of advancing public debate on the longterm priorities of government. ${ }^{3}$

\footnotetext{
${ }^{3}$ The report surveyed 550 historians, political scientists, sociologists, and economists. It found that their three top priorities for the next fifty years were increasing arms control and disarmament; increasing health care access for low-income Americans; and expanding and protecting the right to vote (Light 2001, 9).
} 


\section{Strategic Forecasting in Practice}

\section{President Nixon's National Goals Research Staff}

Within the US federal government, the acme of strategic planning was the short-lived National Goals Research Staff. Created by President Nixon in 1969, it was disbanded the following year, having produced just one report (NGRS 1970). The problem was not its mandate - which would still be appropriate today. Established within the Executive Office of the President, the NGRS was tasked to carry out effective scenario planning, by:

"forecasting future developments, and assessing the longer range consequences of present social trends; measuring the probable future impact of alternative courses of action, including measuring the degree to which change in one area would be likely to affect another; estimating the actual range of social choice ... in light of the availability of resources and possible rates of progress; developing and monitoring social indicators that can reflect the present and future quality of American life ... summarizing, integrating and correlating the results of related research activities being carried on within the various Federal agencies, and by State and local governments and private organizations." (National Goals Research Staff 1970)

The reason why the NGRS collapsed so quickly was simple - political infighting (Grant 1988 , 47). In the highly politicised environment of the White House, long-range planning becomes fraught with difficulty. Yet it is no less important because of that. While the Office of Management and Budget ostensibly took over the work of the NGRS, OMB currently has no dedicated foresight unit. Moreover, while the Congressional Budget Office plays a valuable role in fiscal projections, it is constrained in its ability to propose policies to address upcoming challenges. Today, strategic planning within the US federal government is substantially less advanced than it is in the British Government.

\section{Victoria's Policy Development and Research Branch}

In Victoria, long-range planning has a somewhat controversial legacy. During Jeff Kennett's first term (1992-95), a high-level Strategic Policy and Research group was established in the Department of Premier and Cabinet. However, the unit was subsequently disbanded by the head of the Cabinet Office, on the basis it was preferable for each policy branch to carry out its own long-term analysis.

Following Kennett's 1999 election loss, the Labor government of Steve Bracks established a Policy Development and Research Branch in the Department of Premier and Cabinet in June 2000. Seeking to avoid the pitfalls of over-politicisation, Bracks created a team that was both smaller, and less closely connected to the Premier's office, than Kennett's Strategic Policy and Research group. According to branch head David Adams, its goal is "not so much to produce a long term agenda as to produce the knowledge on which such decisions could be made - ie. to scope the policy terrain". 
At the time of writing (mid-2002), the Policy Development and Research Branch employed four full-time staff. Two are former professors of public policy, one has a background in social planning, and the fourth is a graduate recruit. In addition, the Branch engages a part-time staff person to undertake statistical analysis work.

At present, the work of the branch takes three general forms:

- short briefs to the Secretary of the Department of Premier and Cabinet or Premier;

- discussion papers (which tell a basic story and put the case);

- more complex discussion papers (which argue the complexities and the logic)

By drawing upon academics, think-tanks, exchange visits, and bureaucratic resources, the goal of the Policy Development and Research Branch is to provide information to the Premier which will substantially assist with long-term strategic thinking in the Victorian Government (Department of Premier and Cabinet 2001). The model is a simple one, which could be replicated by other governments. A key challenge, however, is ensuring that the unit's work is relevant to the government's long-term thinking, without being overly politicised.

\section{The British Government's Foresight Program}

Operating within the Department of Trade and Industry, the British Government's foresight program aims to present a view of what the world will look like in 10 to 20 years. Begun in $1994^{4}$, the program is now in its second five-year cycle, and has broadened its ambit considerably from its original focus on technology and innovation. The program now has 13 foresight panels, which were tasked in 1999 to report on various themes (eg. the ageing population, crime) and sectors (eg. chemicals, financial services). An eminent specialist in the field heads each panel. The panels consulted with business, academics and the broader community, and delivered their first set of reports in December 2000. To date, the foresight program has been responsible for 190 seminars or conferences, and has produced 33 consultation papers. ${ }^{5}$

In the future, there is a good chance that the foresight program will shift to a rolling program of reviews, with varying deadlines according to the complexity of the project. ${ }^{6}$ So far, most emphasis has been placed on science and technology. If the program is to effectively tackle social and economic issues as well, it will probably need to move from

\footnotetext{
${ }^{4}$ The creation of the foresight program followed a recommendation in a 1993 White Paper on science, engineering and technology, entitled Realising Our Potential.

${ }^{5}$ Foresight Steering Group 2001, 13. The response to the foresight program has been mixed. Among academics, the program has been welcomed for encouraging forward-looking research, and for providing a venue for networking (Royal Society of Edinburgh 2001). Industry groups have also welcomed the extra funding for research and development, and the opportunity for networking (Royal Academy of Engineering $2001,4)$. Yet the program has been criticized for the lack of implementation and follow-through of panel recommendations (Institute of Food Research 2001; Royal Academy of Engineering 2001, 5), for having a relatively low public profile (Institute of Physics 2001, 3), and for not being sufficiently connected to government policymaking (Royal Society of Edinburgh 2001).

${ }^{6}$ Research Fortnight 2001; King 2001
} 
the Department of Trade and Industry into either the Treasury or the Prime Minister's office (where it could conceivably merge with the Strategy Unit ${ }^{7}$ ). Yet it has played a role in helping to focus policymakers on long-range challenges, instead of on the short-term disaster management that is all too common in politics.

\section{Scenario Planning at Shell and the Global Business Network}

Since its establishment in 1987, the Global Business Network has aimed to provide private companies with the information and perspectives required to encourage them to understand their possible "alternative futures". 8 Founded by Peter Schwartz, formerly senior member of Shell's prestigious Global Planning Team, GBN provides an unconventional service to its clients - allowing them tap into a range of current trends.

Schwartz advocates paying attention to four topics. First, science and technology - with particular attention to new technologies. Second, events that shape public perceptions, and provoke a deep national response. Third, music, which he argues is important as an expression of particular cultur al attitudes (such as pop in the 1960s or rap in the 1980s), and also as a demonstration of how cultures have fused together. Fourth, those working at the social or intellectual fringes of mainstream society. Schwartz points out that many of those who formed the core of the computer revolution began as hackers, and that companies such as Xerox have deliberately provided a space for "weirdos" within their organization. $^{9}$

Through GBN, Schwartz encourages his clients to diversify their information sources. He contends that policymakers should speak with remarkable people, and read a broad range of books (fiction and non-fiction), magazines (current affairs, literary, international and technological), and reports from universities and think tanks. They should also immerse themselves in challenging environments, by travelling to unfamiliar places, or visiting alternative communities. And finally, Schwartz advocates the creation of online policy networks within and between companies, to share ideas and create cross-disciplinary linkages. ${ }^{10}$

The demands of bureaucratic accountability would make it impossible for government strategic planning teams to follow some of Schwartz's proposals (such as attending rap concerts in order to understand future trends). Yet there is no reason why they cannot follow others - such remaining open to a wide range of information sources, monitoring developments on the fringes, and developing a broad policy network.

\footnotetext{
${ }^{7}$ Established in July 2002, the Strategy Unit is a small independent unit, based at the Cabinet Office, with the mandate of engaging in "blue skies" thinking, and building upon the work of the Performance and Innovation Unit. See http://www.strategy.gov.uk/.

${ }^{8}$ Schwartz 1991, 92

${ }^{9}$ Schwartz 1991, 62-73

${ }^{10}$ Schwartz 1991, 73-92
} 


\section{Skunk Works}

Another useful model is the Lockheed Martin "Skunk Works" team, created to promote innovation in aviation technology. Created in $1943^{11}$, Skunk Works operates with minimal bureaucracy, and in an environment designed to foster creativity. The team places a premium on avoiding titles or protocol, and being removed from the rest of the company. According to Lockheed, the key to its success has been to "identify the best individual talents in aviation, blend and equip them with every tool needed, then provide complete creative freedom so they may arrive at an optimum solution in short order" (Lockheed Martin 2001).

Over the past half century, Skunk Works have played a significant role in several of Lockheed's key inventions, including the U-2 surveillance airplane, the F-117A Stealth fighter and the F-22 tactical fighter. The model has since been emulated by other companies, including Ford, BMW, and McDonnell Douglas, and is often advocated by business writers (Hoenig 2000; Stewart 2001).

As Robert Atkinson (2001) argues, the Skunk Works model could be implemented within the executive branch of government, as a means of encouraging innovation and attracting "creative policy extroverts", who network widely and often travel around the country. The main challenge, however, would be deciding how close a government skunk works team should be to the government. If kept too distant, it might have insufficient influence. But if it were too close, the team might lose its ability to think creatively and focus on the long run.

\section{The way ahead}

Strategic foresight can help to bring Osborne and Gaebler's vision of “anticipatory government" to fruition. Such teams need not be resource-intensive or heavily staffed in order to help governments better anticipate future problems, and respond appropriately. But if they are to avoid the fate of President Nixon's National Goals Research Staff, they must have high-level support, and should endeavour for the most part to avoid the public spotlight.

The successful examples I have outlined above - Victoria's Policy Development and Research Branch, the UK foresight program, the work of Peter Schwartz, and Skunk Works - demonstrate the range within which strategic foresight operates. The Victorian Government's Policy Development and Research Branch in the Victorian Government is small, but combines cross-disciplinary expertise, access to a wide range of information sources, and proximity to the Premier. The UK foresight program is a large public undertaking, focused primarily on technological innovation. Schwartz's work in Shell's Global Planning Group, and the Global Business Network, illustrates a bold model of

\footnotetext{
${ }^{11}$ Skunk Works was started by Lockheed's Chief Engineer, Clarence "Kelly" Johnson. The name derives from the "Skonk Works" of Al Capp's L'il Abner comic strip, where they had a hidden still in a secluded hollow.
} 
strategic foresight in the private sector. And Skunk Works teams offer the potential for fostering creativity in long-range thinking.

Yet while there is much that governments can learn from scenario planning in the private sector, it is important to recognize that the goals of business are substantially different from those that lie at the heart of crafting effective public policy. Schwartz's work is focused on identifying new markets and creating new products - while public policy must be grounded in the institutions of government and the realities of politics. While politics occasionally requires a dose of "creative destruction" (Schumpeter 1975, 82-84), the replacement of old models with new ones is not as essential in policy as in many product markets. Likewise, Lockheed Martin is able to maintain a distance between Skunk Works and the rest of the company, since the Skunk Works team provides the main source of ideas for the company. Such a demarcation would be more difficult to maintain in politics, where there are many competing sources of ideas.

In certain circumstances, a hybrid public-private model is the best way of implementing strategic foresight. The US federal government's use of the RAND Corporation to carry out scenario planning during the Cold War allowed researchers more flexibility than would have been possible with in-house teams. Likewise, the UK's foresight program has benefited from the use of commissioned research. Drawing on outside expertise is particularly desirable in two circumstances - where it is felt that a fresh perspective is required, and where the issue is controversial, and a public report is to be produced.

Establishing good strategic foresight processes in government is no simple task. But it can be made substantially easier by learning from the various examples of foresight programs in the public and private sector. It is also important to know in advance whether the public will be involved, and how removed the foresight team will be from the day-today processes of government. By bringing "the art of the long view" into policy, the result should be a more focused, innovative, and creative government. 


\section{References}

Atkinson, R. 2001. "Thinking Outside the Box". Blueprint. Winter

Beck, U. 1992. Risk Society: Towards a New Modernity. London: Sage

Davis, P. 1996. “Analytic Methods” In B Bradley (ed) 50th Project Air Force: 19461996. Washington, DC: RAND Corporation. 47-51

Department of Premier and Cabinet. 2001. "Who Are We?”. Policy Development and Research Branch. http://www.dpc.vic.gov.au

Foresight Steering Group. 2001. Messages from the Current Round. London: Department of Trade and Industry. http://www.foresight.gov.uk

Friedman, J. 1987. Planning in the Public Domain: From Knowledge to Action.

Princeton, NJ: Princeton University Press

Gidden, A. 1998. The Third Way: The Renewal of Social Democracy. London: Polity Press

Global 2000 Study. 1980. The Global 2000 Report to the President: Entering the Twentyfirst Century. Washington, DC: Government Printing Office

Grant, L. 1988. Foresight and National Decisions: The Horseman and the Bureaucrat.

Lanham, MD: University Press of America

Hoenig, C. 2000. “Skunk Works Secrets”. CIO Magazine. July 1. http://www.cio.com

Institute of Food Research. 2001. "Review of 'Foresight' by the Department of Trade and Industry". http://www.ifrn.bbsrc.ac.uk/science/consultations/foresight.html

Institute of Physics. 2001. "Review of Foresight". April 6.

http://physics.iop.org/Policy/Fore-REV.doc

King, D. 2001. "The Future of the Science Base". Address to the Standing Conference of Physics Professors. London. November 16

Krugman, P. 1994. Peddling Prosperity: Economic Sense and Nonsense in the Age of Diminished Expectations. New York: Norton

Light, P. 2001. Government's Greatest Priorities of the Next Half Century. Brookings Reform Watch No. 4. Washington, DC: Brookings Institution

Lockheed Martin. 2001. "About Skunk Works Palmdale”. http://www.lmtas.com/palmdale/company_overview.html 
Marsh, I. 2002. 'The Prospects for a New 'Federation Settlement' (Through a More Consensual Political System)". Australian Journal of Public Administration. 61(2): 19-32

Mayer, R. 1979. Social Science and Institutional Change. Rockville, MD: National Institute of Mental Health

National Goals Research Staff. 1970. Toward Balanced Growth: Quantity with Quality. Washington, DC: Government Printing Office

Norton, A. 2002. "Prospects for the Two-party System in a Pluralising Political World" Australian Journal of Public Administration. 61(2): 33-50

Osborne, D and Gaebler, T. 1992. Reinventing Government: How the Entrepreneurial Spirit is Transforming the Public Sector. Reading, MA: Addison-Wesley

Osborne, D and Plastrik, P. 1997. Banishing Bureaucracy: The Five Strategies for Reinventing Government. Reading, MA: Addison-Wesley

Porter, M. 1996. "What is Strategy?" Harvard Business Review. 74(6): 61-78

Research Fortnight. 2001. "Foresight review considers rolling future". Research Fortnight. November 7

Robbins, G. 1995. "Scenario Planning: A Strategic Alternative". Public Management. 77: 4-8

Royal Academy of Engineering. 2001. "Consultation on the Foresight Program". http://www.raeng.org.uk/news/publications/submissions/pdfs/Foresight_Review.pdf

Royal Society of Edinburgh. 2001. "Foresight Review".

http://www.ma.hw.ac.uk/RSE/govt_responses/2001/foresight.htm

Schumpeter, J. 1975 [1942] Capitalism, Socialism and Democracy. New York: Harper Perennial

Schwartz, P. 1991. The Art of the Long View: Paths to Strategic Insight for Yourself and Your Company. New York: Currency

Shell International. 1999. Corporate Strategy Board Executive Enquiry: Scenario Planning - Forging a Direct Link with Strategic Decision Making. August 30. www.shell.com/downloads/publications/51245.pdf

Smith, B. 1966. The RAND Corporation: Case Study of a Nonprofit Advisory Corporation. Cambridge, MA: Harvard University Press 
Stewart, T. 2001. "Note to Big-Time CEOs: Start Thinking Small" Business 2.0. August 15

Sturgess, G. 2001. "Beating the bureaucracy: humanising modern government" in P.Botsman and M.Latham (eds) The Enabling State: People before bureaucracy. Sydney: Pluto Press: 187-218

Wiener, A. 1967. The Year 2000: A Framework for Speculation. New York: Macmillan 